\title{
A Discussion on the Curriculum Design of College English and Its Effective Implementation Based on the Need Analysis
}

\author{
Yuan Kong \\ School of Foreign Languages, Jining Medical University, Jining, China
}

\begin{abstract}
Through interviews with the specific needs of English abilities of the graduates in the jobs of different industries and different units, this paper will understand whether their English ability really exceeds the post demand, and will reflect on the College English curriculum according to the actual needs of English in the work. At the same time, after summarizing the English skills required by the graduates in the interview, this paper will further understand the specific situation and implementation effect of the University's highly valued English curriculum, and understand whether it meets the needs of the individual development and social needs of undergraduate students through a questionnaire survey, and find out what problem that needs to be improved. Finally, based on the interview data and questionnaire data, we summarize the learning needs, implementation effects and curriculum problems of College English curriculum, and put forward specific policy recommendations for College English curriculum.
\end{abstract}

Index Terms-College English, needs analysis, curriculum design, effective implementation

\section{INTRODUCTION}

Since the twenty-first Century, with the development of globalization, more and more attention has been paid to the communicative competence of students. Employers are also striving to cultivate talents that are able to adapt themselves to international development. In this process, as one of the only public English courses that all non English majors have to read in higher education, College English teaching is concerned by the society, government and universities. In order to improve the effect of the teaching of Public English, the Ministry of Education formally issued the requirements for the teaching of College English courses in 2007, and reformed the College English. Based on this, this article on the basis of the English curriculum objectives, teaching mode and evaluation mode of domestic university status in-depth understanding, through in-depth interviews of different industry practitioners, understand their needs for English ability in the job, combined with the investigation of the effect of English teaching and the students need to set up the curriculum, in-depth analysis college students English learning needs, existing problems in university English curriculum reflection, and puts forward corresponding policy recommendations.

\section{RESEARCH PRoBLEMS}

According to the understanding of the actual teaching situation of the College Public English and the analysis of the related literature, this paper puts forward the key questions to be solved from four aspects. Include:

(1) What are the actual needs of students in English ability? From the point of view of the graduates, what is the demand for the English ability of the individual, and what kind of learning needs should the College English course meet?

(2) How does the curriculum and implementation effect of the teaching of Public English in the university?

(3) How is the match between the English learning needs of the students and the graduates and the training of the ability of the College English course?

(4) What are the problems in the public English course from the perspective of the needs of students and graduates in the study of Public English? How to improve?

\section{CONCEPT DEFINITION}

\section{A. Language Learning Needs}

\footnotetext{
* Funding Sources: Social Science Planning Research Program of Shandong Province (Grant No. 17CWZJ38); Scientific Research Program of Colleges and Universities in Shandong Province (Grant No. J17RA054); Research Program of Young Teachers' Education and Teaching of Shandong Province (Grant No. 16SDJ232); Key Program in Art Science of Shandong Province (Grant No. ZX2015005); Youth and Adolescents Quality Education Work Planning Program of Shandong Province (Grant No. 13AJY090); Scientific Research Program of Jining Medical University (Grant No. JY2013RW032); The Visiting Scholar Funded Program of Young Backbone Teachers in Jining Medical University; College Students' Innovative Training Project of Jining Medical University (Grant No. cx2017052); Scientific Research Project of College Students in Jining Medical University (Grant No. JYXS2017RW017)
} 
As for the definition of the concept of language learning needs, scholars at home and abroad have put forward different views. Richterich believes that language learning needs are about how to meet the needs of learners to communicate in the use of language (Cai, 2015). Widdowson puts forward the concept of "goal-oriented based" demand, and points out that demand refers to students' academic or professional needs, that is, the purpose of students learning language, the level they want to achieve and the ability they need to master. Berwick divides the demand into two aspects of cognition and feeling demand, the former is based on the factual level, and the latter is based on the subjective needs of the learners. Hutchinson and Waters argue that the learner needs can be divided into two types of target needs and learning needs, and the target demand is considered from the perspective of the curriculum designer which means learning at the end of the course of knowledge and ability to achieve, including the necessary capacity must be reached and currently lack the ability; learning needs is that learners hope to achieve. In this paper, the language learning needs includes two aspects, namely social needs and learning needs, social needs refers to the ability of English demand reflects the graduates in the work position, the learners' needs mainly refers to the students their English level on the objectives of Public English curriculum the expectations and needs of graduates in addition to English work needs (Hu \& Xie, 2014).

\section{B. Course Setting}

As for the definition of curriculum, scholars have put forward different views from different angles. Zhu Xun thinks the curriculum is a dynamic circulation system, including four aspects of curriculum objectives, curriculum content, curriculum implementation and curriculum evaluation. Deng Lei thinks that curriculum arrangement is an arrangement for school or educational administration institution to make school curriculum according to curriculum objectives, curriculum requirements, learners' conditions and specific conditions ( $\mathrm{Hu}, 2014)$. Pan Yu put forward that curriculum is the general plan for training talents, including teaching objectives, tasks, contents, scopes, progress and ways of activities required by training objectives $(\mathrm{Li}, 2014)$. Some scholars will define courses according to the training objectives to set curriculum categories, curriculum type and course of school personnel time arrangement and time allocation, and develop specific learning objectives of the curriculum, learning and learning content, which is mainly composed of curriculum structure and the curriculum content of two parts.

This paper holds that curriculum design is an overall plan of a course, including curriculum objectives, curriculum structure, curriculum implementation and curriculum evaluation. Among them, the curriculum structure includes the classes, the nature of the curriculum, the credits of the course and so on. The implementation of the curriculum includes the teaching materials used in the classroom, the teaching resources and the teaching model and the level of teachers. Course evaluation is the teaching evaluation, which means the way to evaluate the students' learning effect in the course of the course.

\section{Teaching Mode}

There are three main points of view on the definition of teaching model, including: (1) the teaching model is a plan or model. It emphasizes the comprehensive study of the interaction characteristics between the teaching system and the variables of variables, and has the characteristics of the system structure. (2) the teaching mode is the teaching method. The view is that the model is a special teaching method, which is suitable for certain specific teaching situations.(3) the teaching pattern is a teaching structure, which is a typical and stable teaching procedure or configuration established under certain educational ideas.

According to the above point of view, this paper defines teaching mode as a systematic teaching procedure and its strategy system based on teaching idea and teaching goal under specific teaching environment.

\section{Teaching Evaluation}

Teaching evaluation, as an important part of teaching activities, aims to provide effective feedback for teachers and students. Through teaching evaluation, teachers can get feedback information, improve teaching methods and improve teaching quality. Students can understand their learning effects, adjust learning strategies and improve learning efficiency. Teaching assessment includes formative assessment and finality assessment. Formative assessment is a process based and developmental assessment of student learning based on teaching objectives and competency standards, including self-assessment, peer assessment, and teacher assessment of students. The finality assessment is the final and comprehensive assessment conducted at the end of the course. It should be an academic performance test based on the performance of a student's curriculum, not a level test that does not have to be studied by the students.

\section{College Graduates’ Professional Demand for English Ability}

\section{A. The Matching of College Foreign Language Ability Training and Professional Needs}

Compared with the degree of emphasis on the cultivation of foreign language ability in universities, the degree of foreign language ability of the graduates is not highly valued at present. At the same time, there are also differences in the degree of attention of different industries, different units are graduates of foreign language ability, international organizations, catering and accommodation industry, education, scientific research and technology and manufacturing industry to a high degree of attention in English, animal husbandry and fishery, construction industry, mining industry, 
public facilities management, social organizations and other industries on the importance of English a relatively low degree. Attention has been paid to the foreign language ability of graduates from government, state owned enterprises and private enterprises.

\section{B. An Analysis of the Specific Demand for English Ability of Undergraduates}

1. Analysis of the entry requirements

According to interviews with graduates, it is founded that most of the positions except for some state owned enterprises and government posts require English level Four. There is no rigid demand for English when they are recruited, but applicants will mark their English level in their CVs. Foreign companies will have an English interview, read the English project materials and carry out the program, or will have a request for the candidate's graduating college. When entering the workplace, most jobs do not require high standard of English for graduates. Even if they are rigid, they only require four levels (Liu \& Gao, 2016). At present, the graduates of colleges and universities can get the four grade certificate of English at the time of graduation, which can basically meet the foreign language requirements of the employment units. But graduates who apply for foreign companies need better English level, including good English reading ability and listening and speaking skills. They need to be able to read English project materials and express their ideas in English.

2. The specific use of English in the job

In the work, there are great differences in the use of post English in different industries and units. English is the most frequently used in foreign enterprises. In the private sector, the government departments and the state-owned enterprises are relatively weakest. In government departments and state-owned enterprises, in addition to a small number of foreign exchanges, most posts do not involve English in their normal work. Among the most demanding tasks in English, most of them are reading ability, including sending and receiving mail, browsing related English websites, checking English protocol descriptions, reading English documents, etc. Next is listening and speaking ability. The demand for this capability is mainly reflected in the employees of foreign enterprises, including communicating with overseas personnel, participating in company internal meetings, and receiving relevant personnel from abroad (Liao \& Lin, 2015). In addition, people in other units also have certain needs in terms of listening and speaking abilities, for example, government personnel in customs departments need to receive foreign visitors and communicate with foreign passengers.

3. The influence of graduates' English ability on career development

After entering the workplace, the career development of graduates from state-owned enterprises and government departments is less affected by English proficiency level, but a good English level can be an advantage, to a certain extent, to promote the promotion and professional level of graduates. For example, in a state-owned enterprise, the evaluation of a title will have a hard demand for the individual's English level. In the computer industry where English is frequently used, and computer industry that needs to read advanced articles in foreign countries, English ability is a necessary condition for position promotion and future development. In foreign-funded enterprises, English ability has a very important impact on the career development of graduates. If we want to stand out from the competition among our colleagues, good English ability is a prerequisite.

4. The matching of graduates' English ability and post demand

In the interview, some post graduates said they had never used in English, the rest of the graduates said their English ability can meet the basic needs of the jobs in the workplace, especially in reading, but in listening and speaking ability still needs to be strengthened, also need to improve writing ability. Writing and speaking abilities are both abilities of language output. We can see that although graduates are able to read, there are big problems in language output, but they can not be expressed in English well.

\section{Graduates' Introspection and Suggestion to College English Course}

According to the interview results of graduates, it is not difficult to see that although most state-owned enterprises and government departments seldom use English in practical work, but graduates do not think that the setting of College English curriculum is meaningless. On the one hand, although the work is rarely used in English, but a good English level can make you have more choices in the future occupation development, and you can choose some higher requirements for English, but if your English is poor, the space will be very small, on the other hand, although the use of less English in work the but in daily life, English as a language literacy, can improve their quality of life, including more smoothly communicate with the local people in the travel, reading English original, watching English television and others.

In interviews, when asked about the satisfaction of College English courses, only a few graduates expressed satisfaction with the curriculum. They thought there was no problem in school setting, and the effect of English learning mainly depended on their choice and efforts. Most of the graduates think English curriculum has some problems, including the curriculum content boring; teaching methods are mainly taught; the nature of the course as a required, the space is too small, the examination that is more concentrated, practicality is weak, with no significant difference in high school curriculum; single assessment methods; the uneven quality of teachers; time, poor results etc.. In view of these problems, the graduates also put forward some suggestions on the setting up of College English courses, which can be mainly attributed to the following three aspects:

1. To reduce required courses and increase elective courses 
At present, compulsory courses are the main courses in College English courses. No matter whether the students have the need for this, they must take the English courses of the corresponding credits. This for some English level has reached its goal or some small demand for English students, to a certain extent, increased the burden of learning, taking up this time can be used to study other skills and knowledge (Ma \& Zhao, 2016). Therefore, in order to better adapt to the needs of different students, the credits of English required courses can be reduced correspondingly, and the credits of elective courses should be increased accordingly, giving students more room to choose, and choose suitable courses and learning contents.

2. To reduce the grammatical content and increase the teaching of oral English

In interviews, many graduates mentioned that the difference between College English classroom and high school English class is very small, but reading and grammar explanation are still the main ones. Graduates also mentioned that the high school grammar content is enough, and we should pay more attention to listening and speaking and other practical communicative English learning in University, and that is the university English course teaching should focus on, which helps students master listening and speaking skills used in work and life .and is no longer blindly into a grammar point, ultimately "dumb English".

3. To increase the interest of the curriculum and change the way of assessment

At present, many textbooks and classroom materials used in many college English courses follow the old textbooks a few years ago. Textbooks are outdated and lack of interest, which can not stimulate students' interest. Besides, the way of examination is also relatively simple. In the semester or at the end of term, we should examine the usage of word phrases, reading comprehension and other contents, mainly according to the examination results to evaluate the level of students. This makes students less active in English learning and less interested in learning English, and can not better understand their English level. After that, we should pay attention to the interest of curriculum content, update teaching contents, increase more materials related to current affairs or daily life, and improve students' interest. At the same time, the assessment method should be more diversified. Through the phased investigation, group evaluation, personal evaluation and other evaluation methods, we can help students understand their English level and progress better and timely, so as to make adjustments to their learning.

To sum up, most of the posts are not hard to request for the English level of the graduates, but the foreign companies will set up an investigation standard for the English level. In the actual work, the use of English for graduates in various industries is different, the use of foreign enterprises is the highest, and the government department is the lowest. Among them, reading ability is the most used skill, and listening and speaking are the second. On the one hand, due to environmental constraints, less need to communicate with people in English, on the other hand, graduates' listening and speaking abilities are weak. Generally speaking, oral communication can not be done in the form of mail and other written communication. In addition to foreign graduates' ability to speak English, it is a necessary condition for future development. Most other graduates indicate that their English level has little influence on their career development. In general, the English level of the graduates can meet the needs of the present job, but the graduates generally believe that their listening and speaking abilities are still to be strengthened. Therefore, the curriculum design of College Public English has not really met the learning needs of students, and most college graduates are still not satisfied with the current college English curriculum. In view of the existing problems, graduates think that they should increase elective courses, reduce required courses, strengthen listening and speaking training, reduce grammar teaching, increase interest in courses, and adjust examination methods.

\section{REFLECTION ON THE ESTABLISHMENT AND IMPLEMENTATION OF THE PUBLIC ENGLISH COURSE IN UNIVERSITY}

\section{A. The Structure of the Course Is Single and the Choice of Space Is Too Small}

On the one hand, from the perspective of Public English course, in addition to individual colleges and universities offering public Japanese courses and public English courses, the students can choose one to complete the required credits, and other universities are only offering public English curriculum as a compulsory course, where students can only attend course, regardless of whether their needs, regardless of whether the interest must be take at least 12 credits of Public English course. Foreign universities will offer different language courses as general elective courses, forming a complete language curriculum system. For example, Cornell University has 50 language courses. Students can read according to their needs and improve their general knowledge. Combined with the investigation, industry demand and graduates occupation development of the data and the results of the interview graduates, some of the jobs that the students' English ability is not high, even a lot of jobs and never use English, so not all students need to enroll in public English classes to reach a certain level of ability. The results of the questionnaire also show that nearly $45 \%$ of the students think that the public English course should be offered as a general elective course. This ensures that students have more choices, and they can choose corresponding courses according to their interests and development needs, so as to effectively improve their language literacy and general knowledge.

On the other hand, from the perspective of the public English course, the public English class is still a required subject, and the elective course is too small. In most colleges and universities, the public English class is 12 credits, of which 10 credits are required for the required courses, and the elective course accounts for only 2 credits. The results of the questionnaire survey and the results of interviews with graduates showed that students wanted more English elective courses. The English level of each student is different, although each school carries out the entrance examination and 
makes a stratified teaching according to the exam results. But in fact, all levels of the students learning content is still similar, and students English proficiency part better still have to attend some basic courses to improve their English ability does not help, and they also hope that according to their ability and interest in studying the corresponding courses to improve their own ability. In addition, the students have a strong demand for the professional English class, and there are not many specialized English classes set up in the University.

\section{B. The Course Setting Deviates from the Target and the Demand Is Not Satisfied}

In 2007 the Ministry of Education issued College English curriculum requirements which pointed out that the goal of College English teaching is to cultivate students' comprehensive ability of using English, especially listening and speaking ability, so that they can use English to communicate effectively in the future study, work and social activities, while enhancing their self-learning ability, improve the comprehensive cultural literacy and in order to meet the needs of China's social development and international exchanges. It is obvious that the ability of listening and speaking is the most important thing in the teaching of College English courses. However, this is not reflected in the current public English course in Colleges and universities. According to the curriculum setup of several universities involved in the survey, the credits of English listening and speaking course are still less than that of reading class. The results of questionnaire survey show that $79 \%$ of the students have read the ability of reading, which has reached the general requirements of the Curriculum Requirements, and nearly $60 \%$ students have achieved higher requirements. But the students' listening and speaking ability is relatively weak, and $34.3 \%$ and $31.2 \%$ can not use English for daily communication and daily English conversation. More than 3/4 of the students believe that oral English course should be added to class hours, and another $46 \%$ think that listening course should be added to class hours.

\section{The Content of the Course Is Lack of Interest and the Validity of the Assessment Method Is Insufficient}

In interviews with graduates, graduates said that the textbooks and classroom materials used in College English courses follow the old textbooks a few years ago. Textbooks are obsolete and lack interest, which can not stimulate students' interest. Similarly, in the questionnaire survey, it was also found that students' interest in the course content was very low.

The method of assessment is single, and no scientific and reasonable evaluation system has been formed. In the public English curriculum, assessment of the course grade is mainly in the course of the semester or the end of the semester to examine the use of words and phrases, reading comprehension and other content, to evaluate the students according to the examination results, although the assignments have gradually been incorporated into the total score, but the proportion of small, test scores are still in dominant position (Xu, 2014). As the four and six level examination of College Students' English level, $41.3 \%$ of the students think they can't reflect their true level. As a whole, the validity of the assessment methods of English courses is insufficient, which can not reflect the true English level of the students, and the evaluation system remains to be improved.

\section{Students Are Inadequately Invested and the Effect of Learning Needs to be Improved}

The curriculum structure is not reasonable, so the students' English learning motivation is weak, and some students in order to credit and had to study English, so they in English learning are passive, they do not focus in class and do not invest the time to consolidate learning, resulting in students' English learning effect. Although freshmen and sophomores need to take English courses every semester, 1/3 of their students haven't changed their English level since entering school, and even $27 \%$ of them didn't have the same level of English as before.

\section{E. The CET 4 and 6 Backwash Teaching and Course Trend Should Be Tested}

Although the creation of the subject of Public English class is the University, but the University offers courses in one hand should be in accordance with the requirements issued by the Ministry of education curriculum, on the other hand, due to the measure of the quality of personnel training, four, six pass rate is still a noticeable index, which opened in university English courses, often considered by rate of four and six grade, so the courses and contents accordingly tend to test, such as the current college reading courses accounted for a large, relatively speaking curriculum module, the highest proportion is four and six grade reading test. Although since the beginning of January 2006, four, six exam hearing the proportion rose from $20 \%$ to $35 \%$, but for a long time, in favor of reading teaching in Colleges and universities, subject to the level of teachers, school facilities, and can quickly adjust the course content, and College English curriculum at present, reading still the dominant candidate, that still exists. In addition, due to the imbalance between Chinese college students in the region and school, the current four and six level examinations can not meet the needs of different levels of candidates. Therefore, in a sense, four and six level oriented curriculum can not meet students' learning needs.

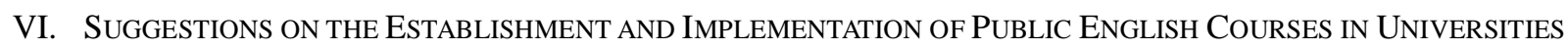

In view of the above conclusions, this paper believes that measures can be taken to improve the following aspects.

\section{A. Increasing the Class of Courses form a Scientific and Reasonable Curriculum System}

First, the curriculum system is adjusted based on the English needs of graduates and daily life and the needs of 
students in English courses. Although English is an international language, its importance in personal development is undeniable, but not all people need to have good English ability (Wen, 2014). High school and previous English learning has been able to meet the needs of some industry positions and graduates' daily life needs, and no longer need to offer English courses in public compulsory courses in universities. English curriculum can be used as a module in general elective courses. Modules can include language courses based on skill training, thematic courses based on cultural understanding and career oriented special language use courses. According to their own school running characteristics and location, each school assigns the proportion of corresponding English courses in the module, giving students more choices and improving their listening and speaking abilities (Zhang, 2014).

In addition, colleges and universities according to their own teaching level and teaching practice, set up other categories of small languages general elective course, such as Japanese, French, Italian, for with us or have different development needs of students elective, enhance students language literacy, cultivate diversified talents, and meet the individual needs of social development.

According to the actual needs of students and the particularity of their majors, proper English courses can be set up properly, so as to improve their professionalism, play the instrumental role of English, and promote the improvement of professional knowledge with the improvement of professional English ability.

\section{B. Improving the Contents and Methods of the Curriculum As Well As the Evaluation System}

In view of the problems such as lack of interest in curriculum content and outdated content, College English teachers should keep pace with the times, enrich and improve curriculum contents, and are no longer a textbook for ten years. But according to the characteristics of the students and the development of the society, we choose the materials that conform to the students' learning level and the development needs, and improve the students' interest in learning (Yang, 2014). In the course of the teaching methods, in addition to teaching the traditional teaching way mainly, can also be through group teaching, problem based teaching, based on the task of teaching and network teaching based on various teaching methods, strengthen the teacher-student interaction, students interaction, improve the degree of attention to the students in the classroom, avoid the "recessive truancy phenomenon".

On the way of assessment, the public English Curriculum in every school should strengthen the construction and improvement of formative evaluation system. Teachers should pay attention to the improvement of students' ability in the usual classroom teaching, and give feedback in time, so as to form a good incentive mechanism (Lu, 2015). To improve students' performance in classroom performance and homework evaluation in comprehensive evaluation, combined with student self evaluation and teacher evaluation, we can comprehensively evaluate students' English level. In addition, we should make scientific and reasonable evaluation standards, improve the validity of the English proficiency test, and reflect the real English level of the students.

\section{Enriching the Course and Creating a Language Environment}

Language learning can not achieve good results only through the teaching of classroom teachers. The essence of the existence of language is to communicate and communicate, and only through continuous practice and practice can a good result be achieved. Stanford University, Harvard University and other world-class university teaching while offering a language course are very focused on the class of language learning, the source structure diversification advantages, carry out rich social activities and academic lectures to create a good language learning environment (Wang, 2015). Although not all foreign universities in the world can have more English speaking students, they can still create good language learning atmosphere by offering English corner, giving lectures in English and giving speeches in English. Some schools that have many overseas students can also invite students to participate in class activities, strengthen interaction between foreign students and students, and improve their language proficiency and communicative competence in practice.

\section{Strengthening Guidance and Improving Students' Learning Motivation}

In the course of Public English learning, some students can have a good plan for their own learning and have a clear learning goal, so they have strong learning motivation, can take the initiative to do the study under the class, and have achieved good learning results. However, some students lack planning for their own learning and are also confused about the future. Therefore, with the psychology of "one step at a time", learning is always in a passive position. Although English classes have never been absent, but they are not in the classroom, and their English proficiency is not going to go backward. It was not until the senior grade did not find that his future work had a high demand for English, but regretted. Therefore, while teaching knowledge, teachers should strengthen their guidance to the students, especially for the students in the lower grade (Zhang, 2016). On the one hand, to strengthen the occupation planning education for students, guide students to develop a reasonable learning and occupation planning, improve the learning motivation; on the other hand, teachers can do learning strategies and learning guides, and guide students to do self supervision and management, to improve the efficiency of learning of students and to improve the learning effect.

\section{E. The Government Should Expedite the Reform of the English Proficiency Test and Push Back the Curriculum Adjustment of Colleges and Universities}

Although universities have greater autonomy in curriculum setting, but the existence of level four or six still affects 
university curriculum and content arrangement to a large extent. So if you want to further adjust the curriculum in Colleges and universities, the government needs to carry on the corresponding reform of English listening and speaking ability, increase the proportion of the assessment, through the evaluation of candidates for English proficiency test objectively, to adjust the curriculum in colleges, and focus on students' English application ability really. In this regard, the government has made the effort, the Ministry of education is developed China English ability rating scale, and with the support of the National English proficiency test level, which will serve as the first covering our entire education English teaching, learning and assessment of ability standard, will achieve the mutual recognition of communication in English teaching a "one-stop" and a variety of learning outcomes. In addition to the description of listening, speaking, reading and writing skills, the Chinese English proficiency scale constructs a pragmatic competence scale. The scale also includes the translation and interpreting ability scale, which fills the gap between the language proficiency scale at home and abroad (Zhu \& Ma, 2014). In a word, it is necessary to establish a unified English assessment system to become a Chinese version of IELTS / TOEFL that everyone can participate in. The new national English proficiency test is expected to be phased out by 2020.Although the English proficiency test level has not yet introduced, from the current knowledge about the related English grade examination, the examination is different from the four, six exams, only two exams will determine the students' English level, but there is a series of test, to different levels the examinee more objective and comprehensive assessment, I also hope the government can really promote the reform of university curriculum adjustment, and college students have in the public English Curriculum in middle school, learn to use, to meet the needs of the individual development and the future occupation.

\section{CONCLUSION}

By understanding the needs of graduates in their positions and the learning effects and needs of college students in College English courses, we reflect on the curriculum design of Public English in Colleges and universities, and summarize the problems existing in the current college English curriculum. On this basis, it puts forward feasible suggestions for improvement, which is conducive to further promoting the reform of College English curriculum, improving the teaching effect of College English, and meeting the needs of individual development and social economic development.

\section{REFERENCES}

[1] Cai, J. G. (2015). "A Summary of the Four Position Disputes in the History of College English Teaching in China and Its Enlightenment." Chinese University Teaching (10): 15-20.

[2] Hu, K. B. \& L. X. Xie. (2014). "Research on the Future Development of College English Teaching in China." Foreign Language World (3): 22-26.

[3] Hu, S. F. (2014). "An Aalysis of College Students' English Learning Needs -- Taking Guangxi University as an Example." Overseas English (5): 35-36.

[4] Li. G. (2014). Application of Formative Assessment in Oral English Learning Evaluation. Chongqing: Sichuan International Studies University.

[5] Liao, B. L. \& S. H. Lin. (2015). “A Discussion on the Reform of College English Course.” China Higher Education Research (1): 96-101.

[6] Liu, L. G. \& L. H. Gao. (2016). “A Classification of College Students' Learning Motivation: A Study Based on Q Method.” The Assessment of Higher Education in China (1): 18-25.

[7] Lu, G. D. (2015). "A Survey of English Social Needs and Its Implications for College English Curriculum Design." Journal of Taizhou University (02): 69-73.

[8] Ma, Y. \& X. J. Zhao. (2016). "An Analysis and Enlightenment of Foreign Language Teaching Mode in American universities From the Perspective of Multiple Identities -- Based on A Case Study in a University in the Midwest of the United States." Journal of Inner Mongolia Normal University 29(3): 102-104.

[9] Richterich. A. (1972). Model for the Definition of Language Needs of Adults Learning a Modern Language. Strasbourg: Council of Europe.

[10] Wang, Y. B. (2015). A Study of English Learning Motivation, Attitude and Needs of Non-English Majors. Jinan: Shandong University.

[11] Wen, Q. F. (2014). "The Controversy between General English and Special English in College English Teaching: Problems and Countermeasures." Foreign Languages and their Teaching (1): 1-8.

[12] Widdowson, H. G. (1981). English for Specific Purposes: Criteria for Course Design. New York: Newbury House.

[13] Xu, X. Y. (2014). “A Research on Foreign Language Teaching System in Stanford University.” Chinese University Teaching (2): 91-96.

[14] Yang, C. Q. (2014). "Investigation and Analysis of Employees' English Needs in Small and Medium Sized Enterprises." College English (Academic Edition) (02): 263-267.

[15] Zhang, Q. (2014). An Experimental Research on Multi Dimensional Interactive Teaching Model of College English. Xi'an: Xi'an International Studies University.

[16] Zhang, T. W. (2016). "The Experience and Enlightenment of National Foreign Language Capacity Building in American Universities: A Case Study of Harvard University.” Foreign Language Education in China 9(1): 3-11.

[17] Zhu, X. \& W. J. Ma. (2014). “An Analysis of learners' needs in curriculum design ”. Foreign Language World (6): 48-56. 
Yuan Kong received her M.A. degree in linguistics. She is currently a lecturer at the School of Foreign Languages, Jining Medical University, Jining, Shandong, China. She teaches various subjects including: English intensive reading, English extensive reading, listening, nursing reading and so on. Her research interests mainly include English language teaching, applied linguistics, cross-cultural communication, etc. 